\title{
Human Rights as Fundamental Conditions for a Good Life
}

Forthcoming in Cruft, R., Liao, S. M., and M. Renzo (eds.), The Philosophical Foundations of Human Rights, Oxford University Press, 2015.

(C) S. MATTHEW LIAO

New York University, 285 Mercer Street, Room 1005, New York, NY 10003; e-mail:

matthew.liao@nyu.edu; www.smatthewliao.com

August 20, 2014 


\title{
Human Rights as Fundamental Conditions for a Good Life
}

\begin{abstract}
What grounds human rights? How do we determine that something is a genuine human right?

In this paper, I offer a new answer: human beings have human rights to what I call the fundamental conditions for pursuing a good life. These are certain goods, capacities and options that human beings qua human beings need whatever else they (qua individuals) might need in order to pursue a characteristically good human life. I call this the Fundamental Conditions Approach. Among other things, I explain how this way of grounding human rights is better than James Griffin’s Agency Approach and Martha Nussbaum’s Central Capabilities Approach, and I also show how it can be compatible with the increasingly popular Political Conceptions of human rights defended by John Rawls, Charles Beitz and Joseph Raz.
\end{abstract}




\section{Human Rights as Fundamental Conditions for a Good Life}

\section{Introduction}

Human rights can offer powerful protection to those who possess them. As such, human rights are frequently invoked in contemporary political discourses. At the same time, many people question whether many purported human rights claims are genuine human rights. For example, the United Nations Universal Declaration of Human Rights (UDHR) lists such rights as the right to employment and periodic holidays with pay. Or, some claim that there is a human right to assisted suicide. ${ }^{1}$ Also, many international declarations on the rights of the child proclaim that children have a right to be loved. ${ }^{2}$ And, more recently, the Director-General of UNESCO announced that there is a human right to peace. Are all these claims genuine human rights?

To determine whether a human rights claim is genuine or not, we need a substantive account of human rights, that is, an account that tells us what human rights we have and why we have these rights. ${ }^{3}$ But what gives content to a substantive account of human rights? In this paper, I offer a new answer: human beings have human rights to what I call the fundamental conditions for pursuing a good life. I call this the Fundamental Conditions Approach. To articulate and defend this approach, I shall do five things. First, I shall explain what I mean by the fundamental conditions for pursuing a good life and why human beings have human rights to

\footnotetext{
1 M.P. Battin, 'Suicide: A Fundamental Human Right?', in M. P. Battin and D. J. Mayo (eds.), Suicide: The Philosophical Issues (New York: St. Martin's Press, 1980), 267-85.

2 S. Matthew Liao, 'The Right of Children to Be Loved', Journal of Political Philosophy, 14/4 (2006), 420-40.

3 James Griffin, 'Towards a Substantive Theory of Rights', in R. G. Frey (ed.), Utility and Rights (Oxford: Blackwell, 1984), 137-60.
} 
these conditions. Second, I shall demonstrate how this approach can explain many of the rights found in the UDHR. At the same time, I shall illustrate how this approach can explain why some of the claims in the UDHR are not genuine human rights. Third, James Griffin has argued that the notion of agency should ground human rights. ${ }^{4}$ I shall explain how Griffin’s Agency Approach differs from the Fundamental Conditions Approach and why the Fundamental Conditions Approach should be preferred. Fourth, my appeal to the notion of a good life will prompt others to think of Martha Nussbaum’s Central Capabilities Approach, which, like the Fundamental Conditions Approach, is in part Aristotelian in spirit. ${ }^{5}$ My complaint with the Central Capabilities Approach as a substantive account of human rights is that it cannot adequately explain a significant number of human rights.

Finally, the Fundamental Conditions Approach (along with Griffin’s Agency Approach and Nussbaum's Central Capabilities Approach) assumes that human rights are those that we have simply in virtue of being human. It therefore belongs to what might be called the Naturalistic Conception of human rights. ${ }^{6}$ In recent years, a new and purportedly alternative

\footnotetext{
4 Griffin 2008, op. cit.

5 Martha C. Nussbaum, 'Capabilities and Human Rights', Fordham Law Review, 66/2 (1997), 273-300; Martha C. Nussbaum, 'Capabilities as Fundamental Entitlements: Sen and Social Justice', Feminist Economics, 9/2-3 (2003), 33-59; Martha C. Nussbaum, Frontiers of Justice: Disability, Nationality, Species Membership (Cambridge: Belknap Press, 2006); Martha C. Nussbaum, Creating Capabilities: The Human Development Approach (Cambridge: Belknap Press, 2011).

${ }^{6}$ What I am calling the Naturalistic Conception has, among other things, also been called the “orthodox” view (Charles R. Beitz, 'Human Rights and the Law of Peoples', in Deen Chatterjee (ed.), The Ethics of Assistance: Morality and the Distant Needy (Cambridge: Cambridge University Press, 2004).; John Tasioulas, 'Taking Rights out of Human Rights', Ethics, 120 (2010), 647-78.).
} 
conception of human rights, the so-called Political Conception of human rights, has become increasingly popular. The Political Conception has been defended by, among others, John Rawls $^{7}$, Charles Beitz ${ }^{8}$ and Joseph Raz ${ }^{9}$. According to the Political Conception, the distinctive nature of human rights is to be understood in light of their role or function in modern international political practice. ${ }^{10}$ Proponents of the Political Conception believe that the Naturalistic Conception "tend[s] to distort rather than illuminate international human rights practice" 11 and should therefore be rejected in favor of its Political counterpart. Since my aim here is to develop what I take to be the correct substantive account of human rights, it will be helpful to discuss the Political Conception of human rights. On behalf of the Natural Conception, I shall argue, among other things, that the theoretical distance between the Naturalistic Conception and the Political Conception is not as great as it has been made out to be. Here it is worth making explicit an assumption that I make but do not defend, namely, I assume that there are positive rights. A person has a positive right if the person is entitled to the provision of some good or service, e.g., a right to welfare assistance; and a person has a negative right if the person is entitled to non-interference, e.g., a right against assault. Although some

\footnotetext{
7 John Rawls, The Law of Peoples: With "The Idea of Public Reason Revisited" (Harvard: Harvard University Press, 1999).

${ }^{8}$ Charles R. Beitz, The Idea of Human Rights (Oxford: Oxford University Press, 2009).

9 Joseph Raz, 'Human. Rights without Foundations', in Samantha Besson and John Tasioulas (eds.), The Philosophy of International Law (Oxford: Oxford University Press, 2010a), 321-38.; Joseph Raz, 'Human Rights in the Emerging World Order', Transnational Legal Theory, 1 (2010b), 31-47.

10 Beitz 2004, p. 197.

11 Beitz 2004, p. 198.
} 
people have claimed that there are only negative rights, ${ }^{12}$ many others have put forward strong arguments in favor of positive rights. ${ }^{13}$ Given this, and given that what I take to be the main competitors to the Fundamental Conditions Approach such as Griffin’s Agency Approach and Nussbaum's Central Capabilities all accept that there are positive rights, I shall not try to defend this assumption here. ${ }^{14}$ My argument can therefore be understood in conditional terms, namely, conditional on the existence of positive rights, human rights should be seen as grounded in the fundamental conditions for pursuing a good life.

\section{The Fundamental Conditions Approach}

To start, let me explain what I mean by a good life and the fundamental conditions for pursuing it. I shall then explain why human beings have human rights to these fundamental conditions.

As I see it, a characteristically good human life, or a good life, for short, is one spent in pursuing certain valuable, basic activities. 'Basic' activities are activities that are important to human beings qua human beings' life as a whole. Sunbathing, for example, is an activity, but is typically not a basic activity, because a human being qua human being's life as a whole is typically not affected if a human being did not go sunbathing. In addition, activities that are very important to an individual human being’s life as a whole may nevertheless not be basic activities, because these activities may not be important to human beings qua human beings' life as a

\footnotetext{
12 J. Narveson, The Libertarian Idea (Philadelphia: Temple University Press, 1988).

${ }^{13}$ See, e.g., Henry Shue, Basic Rights: Subsistence, Affluence, and U.S. Foreign Policy (Second Edition) (Princeton University Press, 1996).

14 See, e.g., James Griffin, 'Welfare Rights', The Journal of Ethics, 4 (2000), 27-43.; Nussbaum 2006, p. 286.
} 
whole. For instance, being a professional philosopher is very important to my life as a whole. But being a professional philosopher is not a basic activity because it is not an activity that is important to human beings qua human beings' life as whole. Similarly, an individual may devote her entire life to the betterment of those in need. This is without a doubt a very moral activity and may also be very important to this individual's life as a whole. But it is not a basic activity, as I understand it, because, again, it is not an activity that is important to human beings qua human beings' life as whole. Finally, basic activities are ones that if a human life did not involve the pursuit of any of them, then that life could not be a good life. In other words, a human being can have a good life by pursuing just some, and not all, of the basic activities. Some of the basic activities are as follows: deep personal relationships with, e.g., one's partner, friends, parents, children; knowledge of, e.g., the workings of the world, of oneself, of others; active pleasures such as creative work and play; and passive pleasures such as appreciating beauty. ${ }^{15}$

It is worth noting that a good life, as I understand it, is not the same thing as an excellent life. An excellent life may require one to have certain accomplishments such as discovering a cure for cancer or having climbed Mount Everest, whereas a good life, as I understand it, does not. My understanding of a good life is closer to what might be called a 'minimally decent life.' But whereas the idea of a 'minimally decent life' is often not explicated, I explicitly understand a good life in terms of pursuing the basic activities and I detail what some of these basic activities are.

\footnotetext{
${ }^{15}$ A way to identify what the basic activities are is through a mixture of empirical research from, e.g., anthropological and sociological studies, and normative theorizing, using something like the method of reflective equilibrium.
} 
From these basic activities, we can derive the contents of the fundamental conditions for pursuing a good life. The fundamental conditions for pursuing a good life are various goods, capacities, and options that human beings qua human beings need, whatever else they (qua individuals) might need, in order to pursue the basic activities. For example, the fundamental goods are resources that human beings qua human beings need in order to sustain themselves corporeally and include such items as food, water, and air. The fundamental capacities are powers and abilities that human beings qua human beings require in order to pursue the basic activities. These capacities include the capacity to think, to be motivated by facts, to know, to choose an act freely (liberty), to appreciate the worth of something, to develop interpersonal relationships, and to have control of the direction of one's life (autonomy). The fundamental options are those social forms and institutions that human beings qua human beings require if they are to be able to exercise their essential capacities to engage in the basic activities. Some of these include the option to have social interaction, to acquire further knowledge, to evaluate and appreciate things, and to determine the direction of one's life. The difference between the fundamental goods and the fundamental options is that the former focuses on the internal, physical conditions for pursuing a good life whereas the latter focuses on the external, environmental conditions for pursuing a good life.

Having the fundamental conditions for pursuing a good life of course cannot guarantee that an individual has a good life; no condition can guarantee this. Rather, these goods, capacities, and options enable human beings to pursue the basic activities. Also, these fundamental conditions are intended to provide human beings with an adequate range of fundamental goods, capacities and options so that they can pursue those basic activities that are characteristic of a minimally decent human life. Now many of the fundamental conditions are 
all-purpose conditions in that they are needed whatever basic activity one aims to pursue. For example, all human beings need food, water, the capacity to think, and the capacity to determine the direction of their lives, whatever basic activity they aim to pursue. But it is possible that some fundamental conditions are needed just for pursuing particular basic activities. For instance, it is possible that the capacity to develop deep personal relationships is needed only if one aims to pursue deep personal relationships. Suppose that this is the case. We can leave it open whether a particular individual will make use of all the fundamental conditions when pursuing a particular kind of good life. This individual's having all the fundamental conditions means that this individual would still have access to an adequate range of goods, capacities and options to pursue those basic activities that are characteristic of a minimally decent human life. This could become important if, e.g., this individual changed his/her mind about pursuing a particular kind of good life. Finally, owing to space, I shall not be able to say much about how much of the fundamental conditions human beings need in order to pursue the basic activities and what one should do when one can only promote some, but not all, of these conditions in a given society. All too briefly, my view is that human beings need enough of these fundamental conditions in order to pursue the basic activity; that when one can only promote some, but not all, of these conditions in a given society, what one should do will depend on the context but that there are likely to be determinate answers; and that the ultimate goal of a given society is to devise policies that would ensure that every person has enough of these conditions.

My notion of the fundamental conditions for pursuing a good life bears some similarities to Rawls's notions of primary goods, which are goods that all individuals are presumed to want, whatever else they may want. ${ }^{16}$ So let me briefly highlight some of the differences. One

16 John Rawls, A Theory of Justice (Oxford: Oxford University Press, 1971). 
difference is that Rawls is interested in social rather than natural primary goods, where, for Rawls, social primary goods include such things as rights, liberties, powers and opportunities, income and wealth, and a sense of self-respect, while natural primary goods include such things as health, vigor, intelligence and imagination. ${ }^{17}$ By contrast, as I conceive it, the fundamental conditions for pursuing a good life would include some natural primary goods such as health. Another difference between the two is that a person who is severely handicapped may have all the primary goods (income, wealth, liberties, and so on) and still not have all the fundamental conditions for pursuing a good life, because he may lack certain capacities necessary to pursue the basic activities.

In my view, these fundamental conditions for pursuing a good life ground human rights because having these conditions is of fundamental importance to human beings, and because rights can offer powerful protection to those who possess them. The former is true because if anything is of fundamental importance to human beings, then pursuing a characteristically good human life is; pursuing a good life is the first and foremost aim of most human beings. And it seems clear that if we attach a certain importance to an end, we must attach this importance to the (essential) means to this end. For example, if we care about making a cake, then we must care about the (essential) ingredients that would enter into making this cake such as flour, water, sugar, eggs, and raising agents. Losing any of these essential ingredients is tantamount to losing the cake itself. Given this, since pursuing a good life is of fundamental importance to human beings, having the fundamental conditions for pursuing a good life must also be of fundamental importance to human beings.

\footnotetext{
17 Rawls 1971, p. 62.
} 
That rights can offer powerful protection to those who possess them is well known. ${ }^{18}$ By their nature, rights secure the interests of the rightholders by requiring others, the duty-bearers, to perform certain services for the rightholders or not to interfere with the rightholders' pursuit of their essential interests. In addition, at least on certain structural accounts of rights, rights typically prevent the rightholders’ interests from being part of a first-order utilitarian calculus. ${ }^{19}$ This means that if a rightholder has a right to something, $\mathrm{V}$, then typically no non-right claims can override the rightholder's right to V. Finally, as some writers have pointed out, because the rightholders are entitled to these services as a matter of rights, this means that the rightholders can simply expect the services without requesting them. ${ }^{20}$ Given the strong protection that rights can offer for the rightholders, and given the importance of having these fundamental conditions to human beings, it seems reasonable that human beings have rights to these fundamental conditions. If this is correct, this provides us with a justification of the idea that human beings have human rights to the fundamental conditions for pursuing a good life.

\section{Rights in the United Nations and the Fundamental Conditions Approach}

The Fundamental Conditions Approach can explain why many of the rights in the UDHR are genuine human rights, but it would also exclude some of the claims in the UDHR as genuine human rights.

\footnotetext{
18 Rights could also have non-instrumental importance in addition to having instrumental importance.

19 See e.g. Dworkin 1977; Nozick 1974.

20 Joel Feinberg, 'The Nature and Value of Rights', in Elsie L. Bandman and Bertram Bandman (eds.), Bioethics and Human Rights : A Reader for Health Professionals (Boston: Little, Brown, 1970), 19-31.
} 
Consider the right to life, liberty and security of person (Article 3). Whatever else human beings (qua individuals) need, they (qua human beings) need life, liberty and security of person in order to pursue the basic activities. If they are not alive; if they cannot freely choose to act to some degree; or if the security of their person is not guaranteed, they cannot pursue the basic activities. Given this, on the Fundamental Conditions Approach, human beings would have human rights to life, liberty and security of person.

Or, consider the right to recognition everywhere as a person before the law (Article 6); the right to equal protection before the law (Article 7); the right against arbitrary arrest, detention or exile (Article 9); the right to a fair and public hearing (Article 10); and the right to be presumed innocent until proven guilty (Article 11). These are things that human beings (qua human beings) need whatever else they (qua individuals) might need in order to pursue the basic activities. In particular, when we pursue the basic activities, conflicts with others are bound to arise. If and when such conflicts arise, we need guarantees that we would be treated fairly and equally. Fair trial, presumption of innocence, equal protection before the law, not arrested arbitrarily, and so on serve to ensure that we would be treated fairly and equally. As such, they are things that human beings (qua human beings) need whatever they (qua individuals) might need in order to pursue the basic activities. As such, the Fundamental Conditions Approach can explain why there are these human rights.

Finally, consider the right to freedom of thought, conscience and religion (Article 18), the right to freedom of opinion and expression (Article 19), and the right to freedom of peaceful assembly and association (Article 20). As we said earlier, one of the fundamental conditions for pursuing a good life is being able freely to choose to pursue the basic activities. In order freely to choose to pursue the basic activities, one must have freedom of expression, thought, religion 
and association. On the Fundamental Conditions Approach, human beings would have human rights to freedom of thought, expression, religion and association.

The Fundamental Conditions Approach would though exclude some of the claims in the UDHR as genuine human rights. To give one example, consider the right to periodic holidays with pay (Article 24). Is there such a human right? On the Fundamental Conditions Approach, the important question to ask is whether paid holidays are a fundamental condition for pursuing a good life. That is, is paid holidays something that human beings (qua human beings) need whatever else they (qua individuals) might need in order to pursue the basic activities? There is no doubt that human beings need some rest and leisure in order to pursue the basic activities. Without time for leisure, human beings would not have sufficient time to pursue the basic activities. Given this, some amount of leisure, in the form of holidays, is a fundamental condition for pursuing a good life. However, it does not seem that paid holidays is a fundamental condition for pursuing a good life, because it seems that human beings can pursue the basic activities even if their holidays were not paid. It might be thought that if holidays were not paid, then some people would not be able to afford to take holidays. But this seems to conflate a person's right to certain minimum welfare, which he has, with a right to paid holidays. If a person cannot afford to take time off work unless his holidays were paid, this person has a human right to certain minimum welfare assistance. But he does not have a human right to paid holidays, because paid holidays is not a fundamental condition for pursuing a good life. Note that while there may not be a human right to paid holidays, this does not mean that there could not be a legal right to paid holidays. It goes without saying that there are other sources of normativity besides human rights (e.g. consideration of justice and/or equality) and some of them may ground social goods such as paid holidays. 


\section{Why not just agency?}

In On Human Rights and in a series of articles, Griffin has argued that the notion of agency should determine the content of human rights. ${ }^{21}$ Griffin writes,

What seems to me the best account of human rights is this. It is centred on the notion of agency. We human beings have the capacity to form pictures of what a good life would be and to try to realize these pictures. We value our status as agents especially highly, often more highly even than our happiness. Human rights can then be seen as protections of our agency - what one might call our personhood. ${ }^{22}$

By agency, Griffin means our autonomously choosing a conception of a worthwhile life (autonomy), our being at liberty to pursue this conception (liberty), and our having minimum material provision and education. ${ }^{23}$

There is much to be said in favor of Griffin’s Agency Approach. For one thing, agency is clearly of great importance to human beings. Without some of it, human beings would not be able to bring about any actions at all, let alone actions necessary for a moral and purposeful life. Given this, it seems highly appropriate to protect it with human rights, which offer strong

${ }^{21}$ Griffin 2008; Griffin 2000; James Griffin, 'Discrepancies between the Best Philosophical Account of Human Rights and the International Law of Human Rights', Proceedings of the Aristotelian Society, CI (2001a), 1-28.; James Griffin, 'First Steps in an Account of Human Rights', European Journal of Philosophy, 9/3 (2001b), 306-27. This sections draws on S. Matthew Liao, 'Agency and Human Rights', Journal of Applied Philosophy, 27/1 (2010), $15-25$.

22 Griffin 2001a, p. 4.

${ }^{23}$ Griffin 2001b, p. 311. 
protections for its possessors. ${ }^{24}$ Also, the Agency Approach does appear to be able to help us determine which human rights are real. For example Griffin’s derivation of rights such as the right to life and the right to freedom of expression from the notion of agency seem plausible. ${ }^{25}$

This said, Griffin’s Agency Approach also faces a number of issues. ${ }^{26}$ I shall discuss two in order to highlight the difference between Griffin’s Agency Approach and the Fundamental Conditions Approach. First, there is an issue of whether agency should be the sole ground for human rights. ${ }^{27}$ To understand this concern, it is useful to begin by pointing out that Griffin has

\footnotetext{
${ }^{24}$ Griffin 2001b, p. 313.

25 See Griffin 2008, Chs. 12 and 13.

${ }^{26}$ For an excellent discussion of some of the problems that Griffin’s approach might face, see John Tasioulas, 'Human Rights, Universality and the Values of Personhood: Retracing Griffin's Steps', European Journal of
} Philosophy, 10/1 (2002), 79-100.

${ }^{27}$ Lest this lead to confusion, let me note that Griffin does mention a second ground for human rights, what he calls practicalities, which, as he explains, help to make the content of a particular human right "determinate enough to be an effective guide to behaviour ...” (On Human Rights, pp. 37-39). For my purpose, we can leave this aside, because I am interested in standalone grounds for human rights, that is, those grounds that are not parasitic on other grounds for human rights. For example, since the role of practicalities is to make human rights that are grounded in some other way, e.g., agency, more determinate, practicalities are parasitic on other grounds for human rights, and are therefore not standalone grounds for human rights. In fact, the requirement of practicalities seems to be a reasonable requirement for any standalone ground for human rights, since any standalone ground for human rights should be determinate enough to be an effective guide to behavior. Hence, when I claim that Griffin believes that 'agency is the sole ground for human rights,' I am taking him to be holding the view that agency is the sole standalone ground for human rights, which I believe he does. Also, when I investigate whether there could be other grounds for human rights, I am interested in whether there could be other standalone grounds for human rights. To save words though, I shall leave out the word 'standalone' throughout the rest of the paper. 
what might be called a wide notion of agency, because he holds that agency is valuable only in the context of a good, flourishing life. In contrast, a narrow notion of agency would regard agency as being valuable in and of itself regardless of how it might contribute to a good, flourishing life. As Griffin says, autonomy and liberty, the two core values that make up his notion of agency, are "elements of a good life ... features that characteristically enhance the quality of life," but they do not exhaust all the elements of a good life - other elements include freedom from great pain, accomplishing something in the course of one's life, understanding certain moral and metaphysical matters, deep personal relations, and so on. ${ }^{28}$

However, given that Griffin holds that agency is valuable only in the context of a good, flourishing life and given that he accepts that in addition to agency, there are other elements of a good life such as freedom from great pain, understanding, deep personal relations, and so on, which can be used indirectly to shape agency, this raises the question of whether agency should be considered the sole ground for human rights. For example, consider the paradigmatic human right not to be tortured. The fact that torture undermines one’s agency by undermining one's capacity to decide and to stick to the decision is certainly an important factor in deciding that torture violates a human right. ${ }^{29}$ But it seems that another important factor in deciding that torture violates a human right is that it causes great pain. Griffin insists though that the notion of agency by itself can adequately explain such human right as the right against torture. ${ }^{30}$ So let us consider his arguments.

\footnotetext{
28 Griffin 2008, p. 36.

${ }^{29}$ Griffin 2008, pp. 52-53.

${ }^{30}$ As another example, while education is important for autonomy, it seems that the value of understanding is also sufficiently important to human life that it could provide its own independent contribution to the existence of a
} 


\section{According to Griffin,}

Torture has characteristic aims. It is used to make someone recant a belief, reveal a secret, 'confess' a crime whether guilty or not, abandon a cause, or do someone else’s bidding. All of these characteristic purposes involve undermining someone else's will, getting them to do what they do not want to do or are even resolved not to do (my italics). ${ }^{31}$

Griffin then offers two arguments to support his claim that the human right against torture can be adequately explained by the notion of agency alone.

First, Griffin accepts that when asked what is wrong with torture, the obvious response is that it causes great pain. However, he argues that causing pain cannot be why torture violates a human right, because there are many cases of one person's gratuitously inflicting great pain on another that are not a matter of human right violation. For example, consider

Callous Partner: There is an unsuccessful marriage in which the first partner treats the second partner callously, and the suffering endured by the second partner over the years is arguably worse than a short period of physical torture. ${ }^{32}$

Griffin argues that in this case, the first partner, simply by gratuitously inflicting great pain on the second partner, does not thereby violate the second partner's human right.

Second, Griffin argues that undermining someone else’s agency without causing great pain is sufficient for there to be a human right violation in other cases. For example, consider

\footnotetext{
human right to education. If so, it could also be asked whether Griffin's notion of agency should be the sole explanation for such human right as the right to education.

31 Griffin 2008, p. 52.

32 Griffin 2008, p. 52.
} 
Truth Drug: Instead of torture, one uses truth drugs to extract secrets. ${ }^{33}$

Griffin argues that while Truth Drug does not involve inflicting pain, it does involve undermining an individual's agency, which he believes amounts to a human right violation. As he says,

We could not call [Truth Drug] 'torture' because it is essential to 'torture' that the infliction of great pain be the means. But what concerns us here is whether the painless chemical destruction of another person's will raises any issues of human rights. And it does. It does because painless domination is still a gross undermining of personhood. ${ }^{34}$ Since causing great pain is not sufficient for the existence of a human right against torture, and since undermining agency in, for example, Truth Drug is sufficient for the existence of a human right violation, according to Griffin, this shows that the notion of agency, and not, e.g., causing great pain, is what explains the existence of a human right against torture.

Let me start with Griffin's second argument. Truth Drug may show that undermining agency sometimes violates a human right, but it does not show that undermining agency always violates a human right. Recall that Griffin understands undermining someone’s will or agency as 'getting them to do what they do not want to do or are even resolved not to do.' Suppose that I entice you with the possibility of great pleasure in order to get you to do something you do not want to do or are even resolved not to do. For instance, I offer you lots of money so that you would eat large worms - something you do not want to do or are even resolved not to do. ${ }^{35}$ In

\footnotetext{
33 Griffin 2008, p. 53.

34 Griffin 2008, p. 53.

35 It might be thought that offering someone a large sum of money so that she would do something she does not want to do or are even resolved not to do does not undermine her agency, since she has chosen to accept the offer.
} 
such a case, I may have undermined your agency but this would hardly constitute a case of human right violation. If so, while causing great pain may not always be a sufficient condition for the violation of a human right in all cases, neither is undermining an individual's agency. ${ }^{36}$

However, suppose I am wrong and enticing you with the possibility of great pleasure in order to undermine your agency is a case of a human right violation. Still, this does not seem to be the same kind of human right violation as torture is, which involves inflicting great pain. In other words, the Agency Approach faces the question of explaining how undermining agency through extreme pain might be significantly different from undermining agency through great pleasure.

Griffin’s first argument at best shows that causing great pain is not a sufficient condition for the violation of a human right. It does not undermine the idea that causing great pain is necessary for explaining why torture violates a human right. One significant difference between torture and Callous Partner is that in the latter, the second partner typically can leave the

Two comments. First, this is not how Griffin understands what it means to undermine someone's agency. As said earlier, for Griffin, getting someone to do what she does not want to do or are even resolved not to do is sufficient to undermine that person's agency. Second, there are numerous examples in which it seems that a person's agency has been undermined even though the person has chosen to accept an offer. For instance, the practice of paying subjects large sum of money so that they would sell body parts, e.g. oocytes or organs, or participate in medical research, arguably undermines their agency even though these individuals would have chosen to accept the offer. This may explain why a number of people believe that such a practice is a form of undue inducement.

36 Or, consider another example suggested by an anonymous reviewer: Suppose I decorate your work environment with images of enticing sweets, none of which you notice, but together they give you the idea that you would like a donut break and this prompts you to go to the cafeteria. It seems that I have undermined your agency, but it does not seem that I have violated your human rights. 
marriage, whereas in the case of torture, the individual being tortured typically cannot leave the torture chamber. That the second partner can leave the marriage may explain why in this case, there is not a human right violation, despite the psychological torment the second partner has to endure. Consider instead two couples whose second partners could not leave the marriages (as for example in some cases of forced, arranged marriages). In the case of the first couple, the second partner was treated lovingly and respectful by the first partner. In the case of the second couple, the second partner was subjected to a long period of psychological torment by the first partner. It seems plausible that both cases involve human rights violation in virtue of the fact that the second partner could not leave the marriage. But it seems that there may be an additional form of human right violation with respect to the second couple in virtue of the fact that the second partner was subjected to a long period of psychological torment.

Moreover, the kind of torture that Griffin has in mind, where one causes great pain in order to undermine the victim's capacity to decide and to get the victim to give up information, is what might be called Instrumental Torture. Another kind of torture, call it Intrinsic Torture, involves causing extreme pain just for the sake of causing extreme pain. Since Intrinsic Torture does not aim at undermining the victim's capacity to decide and stick to a decision, it involves less agency-related violations. Even so, it would still be a human right violation. If this is right, it seems that causing extreme pain would play an even more significant and necessary role in explaining why there is still a human right violation in Intrinsic Torture. If all this is right, Griffin has not yet shown that the notion of agency can by itself explain the human right against torture.

The second issue regarding Griffin’s Agency Approach is as follows: Griffin resists allowing the other elements of a good life to ground human rights because he is concerned that 
permitting these elements directly to determine the content of human rights would lead to the case that all the necessary elements of a good life would determine the content of human rights, which Griffin believes, would cause the language of rights to become redundant, diluting the discourse of rights. As Griffin writes,

If we had rights to all that is needed for a good or happy life, then the language of rights would become redundant. We already have a perfectly adequate way of speaking about individual well-being and any obligations there might be to promote it. ${ }^{37}$

Call this the Redundancy Objection.

Griffin is certainly correct that there is no human right to everything necessary for a good life. Suppose that sailing is my passion in life, and, hence, having a yacht is a necessary condition for me to have a good life. It would not follow that I have a human right to a yacht. However, the Fundamental Conditions Approach also has resources to block the Redundancy Objection. To see this, note that the Fundamental Conditions Approach would include all the essential agency considerations in Griffin’s Agency Approach. In addition, it would allow fundamental, but non-agency, considerations such as freedom from great pain also to determine the content of human rights. The Fundamental Conditions Approach can straightforwardly exclude as being a valid human rights claim my need to have a yacht because such a need is not a fundamental condition for pursuing a good life. Indeed, it is not something that human beings (qua human beings) need whatever else they (qua individuals) might need in order to pursue the basic activities.

Lest Griffin wish to criticize the notion of 'fundamental' conditions and argue that one cannot draw a meaningful distinction between these conditions and all the necessary elements of

37 Griffin 2008, p. 34. 
a good life, let me explain why Griffin’s Agency Approach too requires something like the notion of 'fundamental conditions' if it is to be plausible.

Recall that Griffin's main concern against broadening the ground for human rights is that he believes that there is no human right to everything necessary for a good life. For example, I do not have a human right to a yacht, even if having a yacht is a necessary condition for me to have a good life. But a similar worry could be raised regarding Griffin’s Agency Approach, namely, there is no human right to every agency consideration that is necessary for a good life. Continuing with the yacht example, developing the agentic capacity to sail a yacht may be necessary for me to have the necessary agentic capacity for a good life, but I do not have a human right that someone help me acquire this capacity. To prevent the Agency Approach from having such an implication, it seems that Griffin would need something like the notion of 'fundamental' conditions, which would restrict agency considerations to only those that human beings (qua human beings) need whatever else they (qua individuals) might need.

In other words, we can distinguish between agency interests and non-agency interests, where the former kinds of interests are derived from considerations such as autonomy and liberty, and the latter kinds of interests are derived from other elements of a good life such as freedom from pain, understanding, and so on. In addition, we can distinguish between fundamental interests and secondary interests, where fundamental interests are things that human beings (qua human beings) need whatever else they (qua individuals) might need in order to pursue a good life (that is, they are the fundamental conditions for pursuing a good life), and secondary interests are things that human beings need in order to pursue a good life. These two sets of distinctions give us four kinds of interests: fundamental agency interests, fundamental non-agency interests, secondary agency interests, and secondary non-agency interests. 


\begin{tabular}{|l|l|l|}
\hline & Agency interests & Non-agency interests \\
\hline Fundamental & fundamental agency & fundamental non-agency \\
& interests & interests \\
\hline Secondary interests & secondary agency & secondary non-agency \\
& interests & interests \\
\hline
\end{tabular}

On this typology, Griffin’s claim is that only fundamental agency interests should ground human rights, whereas on the Fundamental Conditions Approach, fundamental non-agency interests could also ground human rights. One should see that Griffin's Redundancy Objection need not apply to the Fundamental Conditions Approach because the Fundamental Conditions Approach can exclude secondary non-agency interests as grounds for human rights. More pertinently, the point I am making here is that if Griffin were to criticize the notion of fundamental essential conditions, then he would be unable to block secondary agency interests from grounding human rights. Accepting that secondary agency interests could ground human rights would run counter to Griffin’s aim to restrict the content of human rights. Hence, Griffin’s arguments do not rule out the possibility of a wider account of human rights, which would draw on the notion of agency as well as other elements of a good life.

\section{Why not just capabilities?}

Key to Nussbaum's Central Capabilities Approach are the notions of capabilities and functionings, where capabilities are an individual's real opportunities to choose and to act to achieve certain functionings, and functionings are various states and activities that an individual 
can undertake. ${ }^{38}$ To illustrate, compare a person who is robbed at gunpoint and told "your money or your life" and a person who voluntarily gives money to someone on the street. The two individuals may have the same functioning as they are both engaging in the activity of giving money away. However, they do not have the same capability, because the individual who voluntarily gives money can choose not to do so, while the individual who is robbed at gunpoint does not have the choice.

According to Nussbaum, not all capabilities are good or important. For instance, being able to be cruel is neither good nor important. ${ }^{39}$ Nussbaum argues that the following ten central human capabilities are particularly important, as they are "entailed by the idea of a life worthy of human dignity”: life; bodily health; bodily integrity; senses, imagination and thought; emotions; practical reason; affiliation; other species; play; and control over one's environment. ${ }^{40}$ Nussbaum believes that all human beings are entitled to these capabilities and these capabilities form the basis of human rights. ${ }^{41}$ In particular, to have human dignity, Nussbaum argues that each human being must have enough of each of these capabilities. ${ }^{42}$ Moreover, according to Nussbaum, these capabilities generate constraints that political institutions must meet if they are to be minimally just. ${ }^{43}$ Following Rawls, Nussbaum is particularly keen to argue that her list of the ten central

\footnotetext{
38 Nussbaum 2011, pp. 20-26.

39 Nussbaum 2011, p. 28.

40 Nussbaum 2011, pp. 33-34.

41 Nussbaum 2011, p. 62.

42 Nussbaum 2011, p. 36.

43 Nussbaum 2011, p. 168.
} 
capabilities can be the object of an overlapping consensus among citizens who otherwise have different comprehensive views. ${ }^{44}$

The hallmark, and indeed the strength, of Nussbaum's Central Capabilities Approach is its emphasis on our opportunities to choose to do certain things rather than on what we actually choose to do. For instance, with respect to political participation and religious practices, Nussbaum rightly argues that it is the capability or opportunity to engage in such activities that is the appropriate social goal. The Fundamental Conditions Approach too recognizes the importance of being able effectively to choose do certain things. As noted earlier, one of the fundamental conditions for pursuing a good life is to being able freely to choose to pursue the basic activities.

My concern with the Central Capabilities Approach as an account of human rights is that a significant number of human rights cannot be adequately explained in terms of capabilities. ${ }^{45}$ For instance, capabilities do not seem adequate for explaining what might be called status rights, which are rights that protect our moral status as persons. For instance, in the UDHR, the right to recognition everywhere as a person before the law (Article 6); the right to equal protection before the law (Article 7); the right against arbitrary arrest, detention or exile (Article 9); the

\footnotetext{
44 Nussbaum 2011, p. 169.

45 One could also quibble with Nussbaum's list of central capabilities. For instance, is being able to live with concern for and in relation to animals and plants really a central human capability without which a human life would be undignified? Suppose that it were possible for human beings to live on Mars (or some other planet). Suppose that Mars did not have other animals and plants. Suppose that some human beings were to migrate to Mars. Would the lives of these human beings be undignified because these human beings would not be able to live with concern for and in relation to animals and plants? It does not seem so. Moreover, if human rights were grounded in capabilities, it does not seem that these human beings would be deprived of key human rights.
} 
right to a fair and public hearing (Article 10); the right to be presumed innocent until proven guilty (Article 11) are all status rights, as they protect our moral status as persons.

Capabilities do not seem particularly well-suited to explain these rights, because if they were able to explain these rights, it would imply that one can sometimes choose not to exercise these rights, since capabilities are concerned with our real opportunities to choose. But it does not seem that one can sometimes choose whether or not to exercise these rights. For instance, it does not seem that one can sometimes choose not to be recognized everywhere as a person before the law; choose not to have equal protection before the law; choose to be arrested arbitrarily; choose to have an unfair hearing; and choose to be presumed guilty.

Nussbaum does say that

Only in the area of self-respect and dignity itself do I think that actual functioning is the appropriate aim of public policy. Suppose a state were to say, "We give you the option of being treated with dignity. Here is a penny. If you give it back to us, we will treat you respectfully, but if you prefer, you may keep the penny, and we will humiliate you.” This would be a bizarre and unfortunate nation, hardly compatible, it seems, with basic justice. We want political principles that offer respect to all citizens, and, in this one instance, the principles should give them no choice in the matter. 46

So Nussbaum might grant that capabilities cannot adequately explain status rights, but she might argue that status rights represent only a small fraction of the total number of human rights that exist. However, this response is unpersuasive because, as we have seen, a significant number of human rights are status rights; Articles 6, 7, 9, 10, 11 of the UDHR all contain status rights.

\footnotetext{
46 Nussbaum 2006, p. 172.
} 
Hence, once Nussbaum accepts that capabilities cannot adequately explain status rights, she must also accept that capabilities cannot adequately explain a significant number of human rights.

In addition to status rights, capabilities also cannot adequately explain many children's rights because many children's rights are concerned with functionings rather than capabilities. For example, children have rights to health care, education, name, nationality, be protected from economic exploitation, and so on. These rights are best understood as rights to certain functionings rather than rights to certain capabilities. Nussbaum concedes this. As she says, "For children, however, functioning may be made the goal in many areas." ${ }^{\prime 7}$ Nussbaum does try to minimize the impact of this point on her theory by arguing that these functionings are important for helping children to develop adult capabilities. ${ }^{48}$ However, this response ignores the fact that some children will unfortunately not live to adulthood (e.g. children with terminal cancer). Nevertheless, it seems that these children would still have human rights to certain functionings. If so, this further supports the point that these rights are best understood as rights to certain functionings rather than rights to certain capabilities.

Here it may be useful to point out that in contrast, the Fundamental Conditions Approach can explain these rights. I have previously already showed how the Fundamental Conditions Approach can explain status rights. Here let me explain how the Fundamental Conditions Approach can explain many of the rights that children have. I shall not attempt to be exhaustive. Consider for example children's right to health care and education. Children need to be healthy in order to pursue the basic activities, and to be healthy they need to have access to basic health care. Hence, having access to basic health care is a fundamental condition for pursuing a good

\footnotetext{
${ }^{47}$ Nussbaum 2006, p. 172.

48 Nussbaum 2006, p. 172.
} 
life. Similarly, education is a fundamental condition for pursuing a good life because children need to acquire the basic knowledge to be adequately functioning individuals in their society, and to acquire such knowledge, they need some kind of education. Given that health care and education are fundamental conditions for children to pursue a good life, on the Fundamental Conditions Approach, children would have a right to health care and education.

Consider also the right to have a name and a nationality. Having a name and a nationality is a fundamental condition for pursuing a good life because to pursue the basic activities, children need to know that they are unique individuals deserving of equal respect, and to know this, they need to have their own identity. In modern societies, having a name and a nationality gives one one’s own identity. Hence, having a name and nationality is a fundamental condition for children to pursue a good life. On the Fundamental Conditions Approach, children would have the right to have a name and a nationality.

Given that a significant number of human rights cannot be adequately explained in terms of capabilities and given that the Fundamental Conditions Approach can readily explain these rights, this is a reason to prefer the Fundamental Conditions Approach to the Central Capabilities Approach.

\section{Why not the political approach?}

As I said at the outset, proponents of the Political Conception believe that the Naturalistic Conception of human rights should be rejected in favor of its Political counterpart. I have also said the Fundamental Conditions Approach is a Naturalistic Conception. Since my aim here is to develop the correct substantive account of human rights, it will be helpful to say something about the Political Conception. Owing to lack of space, I shall not attempt to give a full defense of the 
Naturalistic Conception. But I shall do three things. ${ }^{49}$ First, I shall argue that Naturalistic Conceptions can accommodate one of the most salient concerns that proponents of the Political Conception have raised about them. Second, I shall demonstrate that the theoretical distance between Naturalistic and Political Conceptions is not as great as it has been made out to be. Third, I shall point out that a Political Conception, on its own, lacks the resources necessary to determine the substantive content of human rights. If I am right, not only should the Naturalistic Conception not be rejected, the Political Conception is in fact incomplete without the theoretical resources that a Naturalistic Conception characteristically provides.

To start, it will be helpful to provide an overview of different ways of understanding the Political Conception.

\section{A. Political Conceptions of Human Rights}

According to Rawls, "Human rights are a class of rights that play a special role in a reasonable Law of Peoples; they restrict the justifying reasons for war and its conduct, and they specify limits to a regime’s internal autonomy.”50 More specifically, a society’s observance of human rights is necessary for the society to be a member "in good standing in a reasonably just Society of People” and is "sufficient to exclude justified and forceful intervention by other peoples." 51 Human rights, Rawls tells us, are "Necessary conditions of any system of social cooperation. When they are regularly violated, we have command by force, a slave system, and

\footnotetext{
49 This section draws on S. Matthew Liao and Adam Etinson, 'Political and Naturalistic Conceptions of Human Rights: A False Polemic?', Journal of Moral Philosophy, 9 (2012), 1-26.

${ }^{50}$ Rawls 1999, p. 79.

${ }^{51}$ Rawls 1999, p. 80.
} 
no cooperation of any kind."52 Moreover, if a society fails to observe human rights, then, according to Rawls, it cannot complain if external agents interfere in its internal affairs, e.g., by means of economic or political sanction, or even coercive intervention. ${ }^{53}$

Raz agrees with Rawls's idea that human rights characteristically set limits to a society's internal autonomy. ${ }^{54}$ But Raz’s account differs from Rawls’s in two main respects. First, Raz argues that while human rights are primarily rights against states, human rights can be held against international agents and organizations of all sorts, including individuals, groups, corporations, and other potential violating domestic institutions. ${ }^{55}$ Second, Raz argues that Rawls fails to distinguish between the limits of sovereignty and the limits of legitimate authority. ${ }^{56}$ Rawls holds that human rights are necessary conditions of any system of social cooperation, and he believes that conditions of social cooperation can determine the limits of sovereignty. But Raz argues that not every action that exceeds a state's legitimate authority can be a reason for interference by other states. For instance, a state can sometimes be protected from external interference even if it lacks internal legitimacy (e.g., if the external agents are themselves biased and corrupt). If so, the conditions of social cooperation alone cannot determine the limits of sovereignty.

\footnotetext{
52 Rawls 1999, p. 68.

53 Rawls 1999, p. 81.

54 Raz 2010a, p. 328.

55 Raz 2010a, p. 329.

56 Raz 2010a, pp. 330-332.
} 
Beitz argues that the current role of human rights in international political practice extends beyond that of the (pro tanto) justification of foreign interference or intervention. ${ }^{57}$ In particular, it encompasses the broader role of guiding practical judgments about international responsibility or concern. For instance, there is a broad range of non-coercive political and economic measures that states and international organizations can use to influence the internal affairs of societies where human rights are threatened, measures that are better classified as assistance than interference. Moreover, Beitz observes that human rights are also justifications for individuals and nongovernmental organizations to engage in reform-oriented political action. In short, Beitz believes that from the perspective of a theory's attempting to explain the current international practice of human rights, it would be better to take a broader view of the international role of human rights than Rawls’s narrower view.

\section{B. The Concern about Timelessness}

Proponents of the Political Conception have expressed a number of concerns regarding the Naturalistic Conception. The one I shall discuss here is the concern about Timelessness. Beitz and others have observed that, on a Naturalistic Conception, human rights seem to be "timeless all human beings at all times and places would be justified in claiming them." 58 However, they argue that it is not the case that all human beings at all times and places would be justified in claiming the human rights currently recognized by international practice. For example, consider the right to education, in Article 26 (1) of the UDHR, which states that:

\footnotetext{
${ }^{57}$ Beitz 2009, p. 101.

58 Beitz 2004, p. 198; Beitz 2009, p. 57.
} 
Everyone has the right to education. Education shall be free, at least in the elementary and fundamental stages. Elementary education shall be compulsory. Technical and professional education shall be made generally available and higher education shall be equally accessible to all on the basis of merit.

Raz points out that if people have a right to education simply in virtue of their humanity, "it follows that cave dwellers in the Stone Age had that right. Does that make sense? ... The very distinctions between elementary, technical, professional and higher education would have made no sense at that, and at many other times." 59

Beitz argues further that international human rights are intended to play a role in a certain range of societies:

Roughly speaking, these are societies that have at least some of the defining features of modernization: for example, a minimal legal system (including a capability for enforcement), an economy that includes some form of wage labor for at least some workers, some participation in global cultural and economic life, and a public institutional capacity to raise revenue and provide essential collective goods. ${ }^{60}$ Echoing this sentiment, Raz argues that human rights are "synchronically universal," by which he means that all people alive today have them. ${ }^{61}$ If it is essential to Naturalistic Conceptions such as the Fundamental Conceptions Approach that human rights are timeless, but if it is the case that human rights as found in international practice are not timeless, then this seems to call into question the plausibility and validity of Naturalistic Conceptions.

\footnotetext{
${ }^{59}$ Raz 2010b, p. 40.

${ }^{60}$ Beitz 2009, pp. 56-57.

${ }^{61}$ Raz 2010b, p. 41.
} 
In response to this concern, it seems that at least some of the rights that can be found in the UDHR are indeed timeless. For example, consider the human right against torture. There seems to be good reasons to believe that even cavemen had a human right not to be tortured. The same can be said regarding the rights not to be murdered, enslaved, and so on.

Second, recall that when Beitz says that international human rights are intended to play a certain role in modern societies, he takes this to mean societies that have a minimal legal system, an economy that includes some form of wage labor for at least some workers, some participation in global cultural and economic life, and so on. However, there are over a hundred un-contacted tribes in the world today, that is, tribes that have no contact with the outside world. ${ }^{62}$ It seems doubtful that all of these tribes have the defining features of modernization that Beitz speaks of, such as 'some participation in global cultural and economic life.' Should we draw the conclusion that members of these tribes do not have human rights? Such a conclusion seems dubious. If so, why should we not accept that human rights can also apply to past societies that similarly lacked features of modernization?

The same point can be made against one of Raz's reasons for rejecting the idea that human rights are timeless. Raz argues that since many of the most uncontroversial human rights appeal to institutions and make use of distinctions (e.g., the distinction between elementary, technical, professional, and higher education) that could not possibly apply in Stone Age societies, it is senseless to think of such rights as timeless. But such institutions and distinctions also fail to apply in the case of present-day un-contacted tribes. And so, by his own reasoning, Raz would have to admit that members of these tribes do not have, say, the human right to elementary education. But if Raz accepts that members of un-contacted tribes do not have some

62 http://www.survivalinternational.org/uncontactedtribes 
human rights, it seems that he would have to abandon his claim that human rights are synchronically universal, by which he means that all people alive today have them.

Third, there are plausible ways of explaining how there could be contemporary human rights such as the right to elementary education without abandoning the claim that human rights are timeless. For instance, we can distinguish between the aim and the object of a right. The aim of a human right is the goal or end of the human right, and the object of a human right is the means to achieving that goal or end. The proposal is that the aims of human rights are timeless while the objects of human rights may vary across time, location, and society. As long as we are clear that when we say that human rights are timeless, we are referring to the aims of human rights, then the puzzle articulated above should be resolved.

To illustrate, consider the human right to free elementary education. We could say that free elementary education is the object of a right. As such, it makes sense only at a specific time, in a specific location, and in a specific society. By contrast, the aim of the right to free elementary education is to ensure that human beings acquire the knowledge necessary to be adequately functioning individuals in their circumstances, and it does not seem odd to say such an aim was relevant, important, and applied in the context of cavemen. In other words, while cavemen would not have had a right to free elementary school education, it does not seem odd to think that the aim of that right did have normative force in their circumstances, and that it would have generated a different, but similar, object of right for cavemen, e.g., the right to be educated (in a basic way) about how to hunt and gather, assuming that such instruction could feasibly be provided to them. Hence, as long as we are clear that when we say that human rights are timeless, we are referring to the aims of human rights, then the puzzle should disappear. 


\section{Formal Compatibility}

I shall now argue that the theoretical distance between these two conceptions is actually not as great as it has been made out to be. To see this, consider the formal features of both conceptions. According to the Naturalistic Conception, human rights are rights that we have simply in virtue of being human. And, according to the Political Conception, human rights are rights that set limits to a society's internal autonomy (Rawls and Raz) and/or rights that the international community has a responsibility to protect in modern societies (Beitz). Are these two formal features incompatible? One way of seeing that they need not be is to notice that the formal features of Political Conceptions seem to be concerned with the issue of who is responsible for protecting and promoting human rights - that is, the issue of the duty-bearers of human rights while the formal features of Naturalistic Conceptions seem to be concerned with what grounds human rights. Since questions about the grounds and questions about the duty-bearers of human rights are non-overlapping or, at least, need not overlap, it is in principle possible for one to accept both a Naturalistic and Political Conception of the formal features of human rights.

To flesh this point out, let us consider what advocates of Naturalistic Conceptions have actually said about the issue of duty-bearers. For example, D.D. Raphael argues that:

The expression 'a universal moral right' may be used in a stronger sense or in a weaker sense. In the stronger sense it means a right of all men against all men; in the weaker sense it means simply a right of all men, but not necessarily against all men. In the weaker sense, all men may have a right which is, for each of them, a right against some men only. ${ }^{63}$

To keep the discussion simple, let us focus on the:

63 Raphael 1967, p. 65. 
Strong Sense: Human rights are rights against all able persons and agents in appropriate circumstances.

Is Strong Sense incompatible with a Political Conception, according to which human rights first and foremost set limits to a society's internal autonomy (Rawls and Raz) and/or are rights that the international community has a responsibility to protect in modern societies (Beitz)? The two formal features can in principle be compatible given that 'all able persons and agents in appropriate circumstances' can be read as an abstract statement about who the duty-bearers of human rights are, and that 'the state and/or the international community in modern societies' can be read as a more specific formulation of who such duty-bearers are. Indeed, supposing that the relevant 'appropriate circumstances' are those of modernity, if one were to ask advocates of the Naturalistic Conception who the 'able persons and agents' in modern societies are, it seems likely that they would accept that it is first and foremost the state and/or the international community that are the relevant 'able persons and agents.' But if advocates of these two Conceptions would come to the same conclusions about who the relevant duty-bearers of human rights are, this suggests that the two Conceptions can be compatible in this respect.

\section{Formal and Substantive Accounts of Human Rights}

Finally, I argue that Naturalistic and Political Conceptions are not only in principle formally compatible, but that, in fact, the Political Conception is incomplete without the theoretical resources that a Naturalistic Conception characteristically provides. To see this, it is useful to distinguish between a formal and a substantive account of human rights. A formal account provides criteria for distinguishing human rights claims from those that are not human rights claims. A substantive account, by contrast, provides criteria for generating the content of human 
rights. A Naturalistic Conception typically provides us with not just a formal, but also a substantive, account of human rights. In this respect, the Fundamental Conditions Approach is a substantive account of human rights. By contrast, the Political Conception tends to provide us with only a formal account of human rights. This is clearest in Beitz's account. Beitz does not provide a list of human rights that we have, but instead proposes what he calls a "model" of such rights, which has three key elements: ${ }^{4}$

(i) Human rights protect urgent individual interests against standard threats that one might find in the modern statist global order.

(ii) Human rights apply in the first instance to the political institutions of states.

(iii) Human rights are matters of international concern. A state's failure to carry out its responsibilities may be a reason for "second level" agents such as the international community to hold the state accountable for carrying out these responsibilities, to assist the state if the state lacks capacities to carry out these responsibilities, and to interfere in the state if the state is unwilling to do so.

Beitz’s account surely provides us with criteria for distinguishing human rights claims from those that are not human rights claims. To keep things simple, consider (i). According to (i), if something is a human right, then it will protect some urgent individual interest. And if something is not an urgent individual interest, then it will not be protected by a human right. The notion of an urgent individual interest therefore tells us something about the formal features of human rights, but it is unclear what substantive human rights would follow from this notion. Similar things can be said regarding (ii) and (iii).

64 Beitz 2009, p. 109. 
The same can be said about Raz's version of the Political Conception. Raz also does not provide a list of human rights that we have, but he proposes the following three steps as a way to determine whether something is a human right:65 a human right exists if:

(a) there is an individual interest that is sufficient to establish an individual moral right;

(b) states are to be held duty bound to respect or promote this interest; and

(c) states do not enjoy immunity from interference should they fail to respect or promote this interest.

Raz's three-step program would, for example, exclude (from the category of interests protected by human rights) interests that cannot ground individual moral rights or interests that states have no duty to protect or promote. But, again, it is unclear what human rights would follow from this program. So Raz’s account also does not give us a substantive account of human rights.

Rawls does provide us with a list (albeit a very short one) of human rights, but in any case it remains unclear whether Rawls's account provides us with more than a formal account of human rights. To see why, recall that for Rawls, one of the main roles of human rights is to set limits to a society's internal autonomy. This provides us with a criterion for distinguishing human rights claims from those that are not human rights claims. In particular, it says that if something, $\mathrm{X}$, is a human right, then $\mathrm{X}$ will set limits to a society's internal autonomy. And if an individual right, $\mathrm{Y}$, does not set limits to a society's internal autonomy, then $\mathrm{Y}$ is not a human right. However, it is unclear what human rights will follow from this criterion. And so it does not provide us with a substantive standard with which we can determine the content of human rights. However, Rawls also claims that human rights are 'necessary conditions for any system of social cooperation.' So it might be thought that Rawls intended the notion of social

65 Raz 2010a, p. 336. 
cooperation to serve as such a substantive criterion. But this interpretation of Rawls faces two difficulties. First, the idea that $\mathrm{X}$ (a set of human rights) is a necessary condition for $\mathrm{Y}$ (a system of social cooperation) is not equivalent to the idea that $\mathrm{X}$ is based on, or grounded in, $\mathrm{Y}$, and it is the latter sort of relationship that is required for something to serve as a substantive criterion. Compare: the idea that air is a necessary condition for agency is not equivalent to the idea that air is based on, or grounded in, agency; the latter does not even make very much sense. Hence, the claim that human rights are necessary conditions for social cooperation is not the same as the claim that human rights are based on, or grounded in, social cooperation. Given this, the fact that Rawls has claimed the former does not mean that he has claimed the latter. And since the latter is what is required for something to serve as a substantive criterion, the fact that Rawls has not claimed the latter means that it is unclear that Rawls intended the notion of social cooperation to be a substantive criterion.

Second, even if Rawls did intend for the notion of social cooperation to be a substantive criterion, it does not seem to be a plausible one. Not all societies that fail to respect the human rights that Rawls lists command by force. ${ }^{66}$ For instance, it is implausible to think that communities that do not recognize personal private property (one of Rawls's human rights) must command by force. Moreover, it is unclear how one derives the right to personal property from the notion of social cooperation. Hence, a substantive account of human rights based on the notion of social cooperation seems to be fraught with difficulties.

It might be said that the Political Conception was never intended to answer the sort of substantive questions that we have accused it of failing to address. However, if this is right and, in fact, the Political Conception, as a formal account of human rights, leaves the important

${ }^{66}$ Raz 2010a, p. 330. 
problem of generating the content of human rights out of view, then the Political Conception is incomplete. Accordingly, it may very well look to Naturalistic Conceptions such as the Fundament Conditions Approach as a source for generating a substantive account of human rights.

\section{Conclusion}

In this chapter, I argued that human rights should be grounded in the fundamental conditions for pursuing a good life. I showed how this Fundamental Conditions Approach can explain why many of the rights in the UDHR are indeed human rights, but also how this approach can rule out some of the claims in the UDHR as genuine human rights. I also distinguished the Fundamental Conditions Approach from Griffin’s Agency Approach and Nussbaum’s Central Capabilities Approach by arguing, among other things, that Griffin's approach cannot adequately explain the

right against torture and that Nussbaum's approach cannot adequately explain status rights and many children’s rights.

I further defended the Fundamental Conditions Approach as a Naturalistic Conception of human rights against the Political Conceptions of human rights by a) arguing that the distinction between the aim and the object of a right can explain how human rights can be timeless even if many of the human rights proclaimed in international declarations do not appear to be so; b) showing that Naturalistic and Political Conceptions can in principle be compatible at the formal level because the formal features of Political Conceptions seem to be concerned with the issue of who is responsible for protecting and promoting human rights, while the formal features of Naturalistic Conceptions seem to be concerned with what grounds human rights; and c) arguing that the Political Conception tends to offer only a formal account of human rights, which means 
that a Political Conception is, on its own, incomplete, and may very well look to a Naturalistic Conception to provide what it is missing, i.e., a substantive account of human rights. If all of this is right, the Fundamental Conditions Approach offers a real and coherent alternative to existing approaches to human rights and deserves further study in the debate regarding the grounds of human rights. ${ }^{67}$

\section{Bibliography}

Battin, M.P. (1980), 'Suicide: A Fundamental Human Right?', in M. P. Battin and D. J. Mayo (eds.), Suicide: The Philosophical Issues (New York: St. Martin's Press), 267-85.

Beitz, Charles R. (2004), 'Human Rights and the Law of Peoples', in Deen Chatterjee (ed.), The Ethics of Assistance: Morality and the Distant Needy (Cambridge: Cambridge University Press).

Beitz, Charles R. (2009), The Idea of Human Rights (Oxford: Oxford University Press).

Feinberg, Joel (1970), 'The Nature and Value of Rights', in Elsie L. Bandman and Bertram Bandman (eds.), Bioethics and Human Rights : A Reader for Health Professionals (Boston: Little, Brown), 19-31.

Griffin, James (1984), 'Towards a Substantive Theory of Rights', in R. G. Frey (ed.), Utility and Rights (Oxford: Blackwell), 137-60.

Griffin, James (2000), 'Welfare Rights', The Journal of Ethics, 4, 27-43.

Griffin, James (2001a), 'Discrepancies between the Best Philosophical Account of Human Rights and the International Law of Human Rights', Proceedings of the Aristotelian Society, Cl, 1-28.

Griffin, James (2001b), 'First Steps in an Account of Human Rights', European Journal of Philosophy, 9 (3), 306-27.

Liao, S. Matthew (2006), 'The Right of Children to Be Loved', Journal of Political Philosophy, 14 (4), 42040.

Liao, S. Matthew (2010), 'Agency and Human Rights', Journal of Applied Philosophy, 27 (1), 15-25.

Liao, S. Matthew and Etinson, Adam (2012), 'Political and Naturalistic Conceptions of Human Rights: A False Polemic?', Journal of Moral Philosophy, 9, 1-26.

Narveson, J. (1988), The Libertarian Idea (Philadelphia: Temple University Press).

Nussbaum, Martha C. (1997), 'Capabilities and Human Rights', Fordham Law Review, 66 (2), 273-300.

Nussbaum, Martha C. (2003), 'Capabilities as Fundamental Entitlements: Sen and Social Justice', Feminist Economics, 9 (2-3), 33-59.

Nussbaum, Martha C. (2006), Frontiers of Justice: Disability, Nationality, Species Membership (Cambridge: Belknap Press).

${ }^{67}$ I would like to thank Rowan Cruft, Massimo Renze, Rob Shaver, Daniel Khokhar, Carolyn Plunkett, Andrew Franklin-Hall, Nic Southwood, Collin O’Neil, Christian Barry, Daniel Nolan, Rachael Briggs, Rahul Kumar, Kerah Gordon-Solmon, Meena Krishnamurthy, Christine Sypnowich, Adrian Currie, and audiences at the Australian National University, the Queen's University, Kingston, and the University of Manitoba, for their helpful comments on earlier versions of this paper. 
Nussbaum, Martha C. (2011), Creating Capabilities: The Human Development Approach (Cambridge: Belknap Press).

Rawls, John (1971), A Theory of Justice (Oxford: Oxford University Press).

Rawls, John (1999), The Law of Peoples: With "The Idea of Public Reason Revisited" (Harvard: Harvard University Press).

Raz, Joseph (2010a), 'Human. Rights without Foundations', in Samantha Besson and John Tasioulas (eds.), The Philosophy of International Law (Oxford: Oxford University Press), 321-38.

Raz, Joseph (2010b), 'Human Rights in the Emerging World Order', Transnational Legal Theory, 1, 31-47.

Shue, Henry (1996), Basic Rights: Subsistence, Affluence, and U.S. Foreign Policy (Second Edition) (Princeton University Press).

Tasioulas, John (2002), 'Human Rights, Universality and the Values of Personhood: Retracing Griffin's Steps', European Journal of Philosophy, 10 (1), 79-100.

Tasioulas, John (2010), 'Taking Rights out of Human Rights', Ethics, 120, 647-78. 